\title{
Economic Growth And Carbon Emissions In South Africa: An Empirical Investigation
}

\author{
Nicholas M. Odhiambo, University of South Africa, South Africa
}

\begin{abstract}
In this paper we examine the causal relationship between $\mathrm{CO}_{2}$ emissions and economic growth in South Africa - using the newly developed ARDL-Bounds testing approach. We incorporate energy consumption in a bivariate causality setting between $\mathrm{CO}_{2}$ emissions and economic growth, thereby creating a simple trivariate model. Our empirical results show that there is a distinct unidirectional causal flow from economic growth to carbon emissions in South Africa. We also find that energy consumption Granger-causes both carbon emissions and economic growth. We recommend that energy conservation policies, as well as appropriate forms of renewable energy, should be explored in South Africa in order to enable the country to reduce its carbon emission footprint without necessarily sacrificing its output growth. The results apply irrespective of whether the causality is estimated in the short or in the long run.
\end{abstract}

Keywords: Africa; South Africa; $\mathrm{CO}_{2}$ emissions; energy consumption; economic growth

\section{INTRODUCTION}

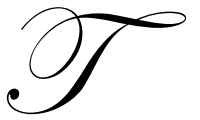

he relationship between carbon emissions and economic growth is based on the so-called Environmental Kuznets Curve (EKC), which posits that the level of environmental degradation and income per capita resembles an inverted U-shaped curve. According to EKC hypothesis, pollution levels increase as a country develops, but begin to decrease as the rising incomes pass beyond a turning point. In other words, there is a threshold level of economic growth beyond which further increase is able to redress the environmental impacts of the early stages of economic development (see also Sun, 1999, Ferda, 2008).

Although a number of studies have examined the relationship between carbon emissions and economic growth in developing countries, the majority of these studies have mainly concentrated on the relevance of the Environmental Kuznet Curve (EKC). Very few studies have gone the full distance to examine the nexus between $\mathrm{CO}_{2}$ emissions and economic growth. Even where such studies have been done, the focus has mainly been on Asia and Latin American countries. Studies on the causal relationship between carbon emissions and economic growth in sub-Saharan countries are very scant. In addition, the majority of the previous studies suffer from three major weaknesses; namely, 1) the use of a bivariate causality test, which may lead to the omission-of-variable bias; 2) the use of cross-sectional data, which does not satisfactorily address the country-specific effects; and 3) the use of a residual-based cointegration test associated with Engle and Granger (1987) and the maximum likelihood test based on Johansen (1988) and Johansen and Juselius (1990), which has been proven to be inappropriate when the sample size is too small (see Nerayan and Smyth, 2005). It is against this backdrop that the current study attempts to examine the inter-temporal causal relationship between $\mathrm{CO}_{2}$ emissions and economic growth, using the newly developed ARDL-Bounds testing approach. By incorporating energy consumption as an intermittent variable in a bivariate setting between $\mathrm{CO}_{2}$ emissions and economic growth, we develop a simple trivariate causality model between $\mathrm{CO}_{2}$ emissions, energy consumption and economic growth.

\section{$\mathrm{Co}_{2}$ Emissions And Economic Growth In South Africa}

South Africa is considered to be the largest economy in Africa. The country is also ranked number 20 globally in terms of the volume of gross domestic product (GDP). The country's current GDP is about US \$704 billion, which is approximately $36 \%$ of the total of sub-Saharan Africa's GDP and $69 \%$ of the total SADC's GDP. 
Despite the fact that South Africa's economy is the largest in Africa, economic growth has consistently shown a mixed trend, especially since the 1980s. For example, during the period 1975 to 1984, the average annual percentage growth in GDP in South Africa was 2.4\%, with the highest growth rate of about 9.2\% being recorded in 1980 . However, this rate decreased dramatically to an average of about 1.4\% during the period 1985-1989 (see African Development Indicators 2002). Between 1990 and 1992, the GDP growth rate remained negative and systematically declined to $-2.1 \%$ in 1992. It was only in 1993 that the downward slide in the South African economy was reversed. In 1994, the GDP growth rate significantly increased to about $3.2 \%$ from about $1.2 \%$ in 1993 . The rate later increased to $4.2 \%$ in 2000 , decreased in 2003 to $2.8 \%$, and increased again in 2004 to $4.5 \%$. By 2005, the GDP growth rate was $5.0 \%$ - the highest rate recorded since 1984 .

On the carbon emissions side, South Africa is considered to be one of the world's highest carbon dioxide emitters. The country is currently ranked $12^{\text {th }}$ in terms of annual carbon dioxide emissions. By 2004 , for example, the country's carbon dioxide emissions totalled 437,032,000 metric tons. Currently, its carbon emissions are estimated to be about (+/-) 451, 000, 000 metric tons." The country's carbon emissions originate mainly from coal, which provides over $70 \%$ of South Africa's energy needs and over $90 \%$ of its electricity needs. It is estimated that between $80-90 \%$ of South Africa's carbon emissions come from coal.

Despite South Africa's high level of carbon dioxide emissions, its status as a "Non-Annex 1 Country" under the Kyoto protocol implies that it has no emission reduction targets during the period 2008-2012. According to the Kyoto protocol, only industrialized and developed countries have legally binding greenhouse gas emission caps, which apply between 2008 and 2012. In other words, the Kyoto protocol exempts all developing countries, including South Africa, from taking legally binding commitments during this first commitment period up to 2012 (see Polity 2007). South Africa, however, has a non-binding commitment to mitigate emissions within its own means under the United Nations Framework Convention on Climate Change (UNFCCC). Currently, the country is pursuing a number of policies that could enable it to reduce its carbon footprint while at the same time exploring other sources of renewable energy as a means of boosting its electricity production. The country's current response to climate policy is built on a number of thematic pillars. These include, among others:

1. reducing greenhouse gas emission and limiting its growth

2. scaling up energy efficiency and electricity demand management initiatives

3. implementing the "Business Unusual" call for action in key sectors, such as the renewable energy sector and transport sector

4. increasing support for new and ambitious research, especially in the field of carbon-friendly technologies, with the focus on the renewable energy and transport sectors

5. identifying and quantifying South Africa's vulnerabilities to climate change and initiating mechanisms for interventions

6. aligning and coordinating the roles and responsibilities of all stakeholders in implementing government policies on climate change. Table 1 shows the trends of $\mathrm{C} 02$ emissions, energy consumption and economic growth in South Africa during the period 1990-2007, as compared to 1980

\section{LITERATURE REVIEW}

While the relationship between energy consumption and economic growth has attracted a great deal of empirical literature in recent decades, the relationship between carbon emissions and economic growth has not been extensively investigated. The majority of the empirical studies on this subject have concentrated mainly on the relevance of the Environmental Kuznets Curve (EKC). According to the Environmental Kuznets Curve (EKC) hypothesis, the relationship between environment and economic development is non-linear and resembles an inverted U-curve. That is to say, environmental damage first increases with increase in income, then stabilizes and eventually declines (see Ang, 2007). Some of the empirical studies, whose findings support the EKC hypothesis, include Hettige et al. (1992), Cropper and Griffiths (1994), Selden and Song (1994), Grossman and Kueger (1995), and Martinez-Zarzoso and Bengochea-Morancho (2004), among others. However, Dinda and Coonndoo (2006), while applying a panel data analysis in a bivariate setting to examine the relationship between income and emissions, find mixed results. In the same vein, World Bank (2007) finds that $\mathrm{C}_{2}$ emissions per capita are positively but moderately correlated with GDP per capita. The study also finds that there is no evidence of an 
eventual decline in emissions per capita at higher per capita income - contrary to the Environmental Kuznets Curve phenomenon. Lise (2006), while using energy consumption as an indicator of environmental degradation, concludes that the relationship between carbon emissions and income in Turkey is linear rather than following an EKC path. Agras and Chapman (1999), while examining the environmental Kuznets curve hypothesis, find that energy price rather than income - was the significant determinant of environmental quality when both variables were included as explanatory variables. This finding raises questions as to whether income level is really an important determinant of environmental quality.

Table1 1: Trends Of $\mathrm{Co}_{2}$ Emissions, Per Capita GDP And Energy Consumption In South Africa

\begin{tabular}{|c|c|c|c|}
\hline Year & $\begin{array}{c}\mathbf{C O}_{2} \text { emissions (metric tons per } \\
\text { capita) }\end{array}$ & $\begin{array}{c}\text { Energy use (kg of oil equivalent per } \\
\text { capita) }\end{array}$ & Per capita GDP (Rand) \\
\hline 1980 & 7.6591 & 2372.24 & 23294 \\
\hline 1990 & 8.1080 & 2591.73 & 21710 \\
\hline 1991 & 3.3280 & 2654.74 & 20170 \\
\hline 1992 & 7.6221 & 2438.14 & 19996 \\
\hline 1993 & 7.9177 & 2527.50 & 20214 \\
\hline 1994 & 8.1608 & 2605.68 & 20412 \\
\hline 1995 & 8.3109 & 2660.97 & 20848 \\
\hline 1996 & 8.0850 & 2645.18 & 20625 \\
\hline 1997 & 8.1179 & 2642.57 & 20675 \\
\hline 1998 & 7.9839 & 2611.96 & 21104 \\
\hline 1999 & 7.7144 & 2549.23 & 21269 \\
\hline 2000 & 7.4106 & 2565.80 & 21663 \\
\hline 2001 & 7.4095 & 2593.23 & 21991 \\
\hline 2002 & 7.8454 & 2511.04 & 22729 \\
\hline 2003 & 7.9443 & 2658.11 & \\
\hline 2004 & 8.1080 & 2828.64 & \\
\hline
\end{tabular}

Source: World Development Indicators (2007); BP Statistical Review of world Energy (2008); SARB Quarterly Bulletin (2008)

Some of the studies that have attempted to examine the relationship between carbon emission and economic growth include Shafik (1994), Holtz-Eakin and Selden (1995), Ang (2007), Jinke et al. (2007), Soytas and Sari (2009), and Sadorsky (2009), among others. Holtz-Eakim and Selden (1995), for example, while examining the relationship between $\mathrm{CO}_{2}$ emissions and economic growth using a panel data analysis, find that there is a diminishing marginal propensity to emit $\mathrm{CO}_{2}$ as economies develop. Shafik (1994) also finds that pollutant emissions are monotonically increasing with income levels. In an attempt to examine the causal relationship between $\mathrm{C}_{2}$ emissions, energy consumption and economic growth, Ang (2007) finds that economic growth exerts a causal influence on growth of population and growth of energy use. However, Soytas et al. (2007), while examining the relationship between carbon emissions, energy use, and income in the US, find that there is no evidence of causality between income and carbon emissions. Similar results were found in Soytas and Sari (2009) in the case of Turkey. According to the author, the lack of a long-run causal link between income and emissions may imply that Turkey does not need to forego economic growth in order to reduce its carbon emissions. Bhattachryya and Ghoshal (2009) argue that the interrelationship between the growth rates of $\mathrm{CO}_{2}$ emissions and economic development is mostly significant for countries that have a high level of $\mathrm{CO}_{2}$ emissions and pollution. In an attempt to empirically examine the relationship between $\mathrm{CO}_{2}$ emissions, energy consumption, income and foreign trade, Halicioglu (2009) finds that income is the most significant variable in explaining the carbon emissions in Turkey. Sari and Soytas (2009) empirically examine the relationship between carbon emissions, income, energy and total employment in five OPEC countries. The authors find that none of the countries under study need to sacrifice their economic growth in order to reduce their emission levels. Apergis and Payne (2009), while examining the relationship between $\mathrm{CO}_{2}$ emissions, energy usage and output in Central America, find that in the short run there is a unidirectional causality from energy 
consumption and real output to emissions, but in the long run there appears to be a bi-directional causality between energy consumption and emissions.

\section{ESTIMATION TECHNIQUES AND EMPIRICAL ANALYSIS}

\section{Cointegration - ARDL-Bounds Testing Procedure}

In this study, we use the recently developed Autoregressive Distributed Lag (ARDL)-Bounds testing approach to examine the long-run relationship between carbon dioxide emissions, energy consumption, and economic growth in South Africa. The ARDL modelling approach was originally introduced by Perasan and Shin (1999) and later extended by Perasan et al. (2001). The ARDL-Bounds model used in this study can be expressed as follows:

$$
\begin{aligned}
& \Delta \operatorname{InCO} 2_{t}=\alpha_{0}+\sum_{i=1}^{n} \alpha_{1 i} \Delta \operatorname{InCO} 2_{t-i}+\sum_{i=0}^{n} \alpha_{2 i} \Delta \operatorname{InENC} C_{t-i}+\sum_{i=0}^{n} \alpha_{3 i} \Delta \operatorname{Iny} / N_{t-i}+\alpha_{4} \operatorname{InCO} 2_{t-1}+ \\
& \alpha_{5} \operatorname{InENC}_{t-1}+\alpha_{6} \operatorname{Iny} / N_{t-1}+\mu_{t} \\
& \Delta \operatorname{InENC} C_{t}=\beta_{0}+\sum_{i=1}^{n} \beta_{1 i} \Delta \operatorname{InENC_{t-i}}+\sum_{i=0}^{n} \beta_{2 i} \Delta \operatorname{InCO} 2_{t-i}+\sum_{i=0}^{n} \beta_{3 i} \Delta \operatorname{Iny} / N_{t-i}+\beta_{4} \operatorname{InENC} C_{t-1}+ \\
& \beta_{5} \operatorname{InCO} 2_{t-1}+\beta_{6} \operatorname{Iny} / N_{t-1}+\mu_{t}
\end{aligned}
$$$$
\Delta \operatorname{Iny} / N_{t}=\delta_{0}+\sum_{i=1}^{n} \delta_{1 i} \Delta \operatorname{Iny} / N_{t-i}+\sum_{i=0}^{n} \delta_{2 i} \Delta \operatorname{InCO} 2_{t-i}+\sum_{i=0}^{n} \delta_{3 i} \Delta \operatorname{InENC} C_{t-i}+\delta_{4} \operatorname{Iny} / N_{t-1}+
$$$$
\delta_{5} \operatorname{InCO} 2_{t-1}+\delta_{6} \operatorname{InENC}_{t-1}+\mu_{t}
$$

where $\mathrm{InCO}_{2}=\log$ of carbon dioxide emissions per capita; InENC = log of energy consumption per capita; Iny/N = the $\log$ of real per capita income; $\mu_{\mathrm{t}}=$ white noise error term; and $\Delta=$ first difference operator.

The bounds testing procedure is based on the joint F-statistic (or Wald statistic) for cointegration analysis (see also Odhiambo, 2009a). The asymptotic distribution of the F-statistic is non-standard under the null hypothesis of no cointegration between examined variables. The null hypothesis of no cointegration among the variables in equation (1) is (Ho: $\alpha_{4}=\alpha_{5}=\alpha_{6}=0$ ) against the alternative hypothesis (H1: $\alpha_{4} \neq \alpha_{5} \neq \alpha_{6} \neq 0$ ). In equation 2, the null hypothesis of no cointegration is $\left(\mathrm{H}_{\mathrm{o}}: \beta_{4}=\beta_{5}=\beta_{6}=0\right)$ against the alternative hypothesis $\left(\mathrm{H} 1: \beta_{4} \neq \beta_{5} \neq \beta_{6} \neq 0\right)$. Finally, in equation 3, the null hypothesis of no cointegration is (Ho: $\delta_{4}=\delta_{5}=\delta_{6}=0$ ) against the alternative hypothesis $\left(\mathrm{H} 1: \delta_{4} \neq \delta_{5} \neq \delta_{6} \neq 0\right.$ ). Pesaran and Pesaran (1997) and Pesaran et al. (2001) report two sets of critical values for a given significance level. One set of critical values assumes that all variables included in the ARDL model are I(0), while the other is calculated on the assumption that the variables are I(1). If the computed test statistic exceeds the upper critical bounds value, then the Ho hypothesis is rejected. If the F-statistic falls into the bounds, then the cointegration test becomes inconclusive. If the F-statistic is lower than the lower bounds value, then the null hypothesis of no cointegration cannot be rejected.

\section{Granger Non-Causality Test}

Once the long-run relationships have been identified in the previous section, the next step is to examine the short-run and long-run Granger-causality between carbon dioxide emissions, energy consumption, and economic growth using the following trivariate model (see also Odhiambo, 2009a; Odhiambo, 2009b; Narayan and Smyth, 2008). 


$$
\begin{aligned}
& \Delta \operatorname{InCO} 2_{t}=\alpha_{0}+\sum_{i=1}^{n} \alpha_{1 i} \Delta \operatorname{InCO} 2_{t-i}+\sum_{i=0}^{n} \alpha_{2 i} \Delta \operatorname{InENC} C_{t-i}+\sum_{i=0}^{n} \alpha_{3 i} \Delta \operatorname{Iny} / N_{t-i}+E C M_{t-1}+\mu_{t} \ldots \\
& \Delta \operatorname{InENC}_{t}=\beta_{0}+\sum_{i=1}^{n} \beta_{1 i} \Delta \operatorname{InENC} C_{t-i}+\sum_{i=0}^{n} \beta_{2 i} \Delta \operatorname{InCO} 2_{t-i}+\sum_{i=0}^{n} \beta_{3 i} \Delta \operatorname{In} y / N_{t-i}+E C M_{t-1}+\mu_{t} \ldots . \\
& \Delta \operatorname{Iny} / N_{t}=\delta_{0}+\sum_{i=1}^{n} \delta_{1 i} \Delta \operatorname{Iny} / N_{t-i}+\sum_{i=0}^{n} \delta_{2 i} \Delta \operatorname{InCO} 2_{t-i}+\sum_{i=0}^{n} \delta_{3 i} \Delta \operatorname{InENC} C_{t-i}+E C M_{t-1}+\mu_{t} \ldots \ldots . .
\end{aligned}
$$

where $\mathrm{ECM}_{\mathrm{t}-1}=$ the lagged error-correction term obtained from the long-run equilibrium relationship.

Although the existence of a long-run relationship between $\mathrm{CO}_{2}, \mathrm{ENC}$ and $\mathrm{y} / \mathrm{N}$ suggests that there must be Granger-causality in at least one direction, it does not indicate the direction of temporal causality between the variables. The direction of the causality, in this case, can only be determined by the F-statistic and the lagged errorcorrection term. While the t statistic on the coefficient of the lagged error-correction term represents the long-run causal relationship, the F-statistic on the explanatory variables represents the short-run causal effect (see Odhiambo, 2008; Narayan and Smyth, 2006). It should, however, be noted that even though the error-correction term has been incorporated in all the equations (4) - (6), only equations where the null hypothesis of no cointegration is rejected will be estimated with an error-correction term (see Narayan and Smyth, 2006; Morley, 2006; Odhiambo, 2009a).

\section{DATA SOURCE AND DEFINITION OF VARIABLES}

\section{Data Sources}

Annual time series data, which covers the 1970 and 2007 period, has been used in this study. The data has been largely obtained from various issues of the International Financial Statistics (IFS) Yearbook and World Development Indicators.

\section{Definitions Of Variables}

- $\quad \mathrm{CO}_{2}$ emissions variable is expressed as metric tons per capita.

- $\quad$ Energy Consumption is expressed as $\mathrm{Kg}$ of oil equivalent per capita.

- $\quad$ Real GDP per capita: The real per capita GDP is computed as follows: Real GDP per capita $(\mathrm{y} / \mathrm{N})=$ Real GDP (y) / Total population (N).

\section{EMPIRICAL ANALYSIS}

\section{Stationarity Tests}

Just like in other time series data, the current study performed appropriate tests for stationarity of all variables used in order to avoid misleading statistical inferences. The results of the stationarity tests in levels (not presented here) show that all variables are non-stationary in levels. Having found that the variables are not stationary in levels, the next step is to difference the variables once in order to perform stationarity tests on differenced variables. The results of the stationarity tests on differenced variables are presented in Table 2 .

The results reported in Table 2 show that after differencing the variables once, all the variables were confirmed to be stationary. The Phillips-Perron and DF-GLS tests applied to the first difference of the data series reject the null hypothesis of non-stationarity for all the variables used in this study. Therefore, it is worth concluding that all the variables are integrated of order one. 
Table 2: Stationarity Tests of Variables on First Difference

\begin{tabular}{|c|c|c|}
\hline Variable & No Trend & Trend \\
\hline \multicolumn{3}{|c|}{ Phillips-Perron (PP) Test } \\
\hline $\mathrm{DLCO}_{2}$ & $-9.599607 * * *$ & $-9.426128 * * *$ \\
\hline DLENC & $-5.188037 * * *$ & $-5.244287 * * *$ \\
\hline $\mathrm{DLy} / \mathrm{N}$ & $-4.106690 * * *$ & $-4.308916 * * *$ \\
\hline \multicolumn{3}{|c|}{ Dickey-Fuller - GLS Test } \\
\hline $\mathrm{DLCO}_{2}$ & $-8.521515 * * *$ & $-8.764371 * * *$ \\
\hline DLENC & $-5.169684 * * *$ & $-5.112923 * * *$ \\
\hline $\mathrm{DLy} / \mathrm{N}$ & $-3.363047 * * *$ & $-3.7224060 * *$ \\
\hline
\end{tabular}

Notes:

1. The truncation lag for the PP tests is based on Newey and West (1987) bandwidth.

2. $\quad * * *$ denotes $1 \%$ level of significance.

3. Critical values for Dickey-Fuller GLS test are based on Elliot-Rothenberg-Stock (1996, Table 1).

\section{COINTEGRATION RESULTS}

In this study, the long-run relationship between $\left[\mathrm{CO}_{2}, \mathrm{ENC}\right.$ and $\left.\mathrm{y} / \mathrm{N}\right]$ is examined using the ARDL-Bounds testing procedure. The ARDL-Bounds testing procedure involves two steps. In the first step, the order of lags on the first differenced variables in equations (1) - (3) is obtained from the unrestricted models by using the Akaike Information Criterion (AIC) and the Schwartz Bayesian Criterion (SBC). The results of the AIC and SBC tests (not reported here) show that while in the case of $\mathrm{CO}_{2}$ and $\mathrm{ENC}$ equations the optimal lag is lag 1, in $\mathrm{y} / \mathrm{N}$ equation, the optimal lag is lag 3. In the second step, we apply bounds F-test to equations (1) - (3) in order to establish whether there exists a long-run relationship between the variables under study. The results of the bounds test are reported in Table 3.

Table 3: Bounds F-Test For Cointegration

\begin{tabular}{|c|c|c|c|c|c|c|}
\hline Dependent Variable & \multicolumn{3}{|c|}{ Function } & \multicolumn{3}{|c|}{ F-test Statistic } \\
\hline$\Delta \operatorname{In} \mathrm{CO}_{2 \mathrm{t}}$ & \multicolumn{3}{|c|}{$\mathrm{CO}_{2}(\mathrm{ENC}, \mathrm{y} / \mathrm{N})$} & \multicolumn{3}{|c|}{$7.0589 * * *$} \\
\hline$\Delta \mathrm{InENC}_{\mathrm{t}}$ & \multicolumn{3}{|c|}{$\mathrm{ENC}\left(\mathrm{CO}_{2}, \mathrm{y} / \mathrm{N}\right)$} & \multicolumn{3}{|c|}{2.3934} \\
\hline$\Delta \operatorname{Iny} / \mathrm{N}_{\mathrm{t}}$ & \multicolumn{3}{|c|}{$\mathrm{y} / \mathrm{N}\left(\mathrm{CO}_{2}, \mathrm{ENC}\right)$} & \multicolumn{3}{|c|}{$6.8218 * * *$} \\
\hline \multicolumn{7}{|l|}{ Asymptotic Critical Values } \\
\hline & \multicolumn{2}{|l|}{$1 \%$} & \multicolumn{2}{|l|}{$5 \%$} & \multicolumn{2}{|l|}{$10 \%$} \\
\hline & $\mathrm{I}(0)$ & $\mathrm{I}(1)$ & $\mathrm{I}(0)$ & $\mathrm{I}(1)$ & $\mathrm{I}(0)$ & $\mathrm{I}(1)$ \\
\hline $\begin{array}{l}\text { Pesaran et al (2001), p. 300, Table CI(ii) } \\
\text { Case II }\end{array}$ & 4.94 & 5.58 & 3.62 & 4.16 & 3.02 & 3.51 \\
\hline
\end{tabular}

Note: * denotes statistical significance at the $10 \%$ level.

The results reported in Table 3 show that there is evidence of cointegration when $\mathrm{CO}_{2}$ and $\mathrm{y} / \mathrm{N}$ are taken as a dependent variable, but not when ENC is taken as a dependent variable. This is supported by the calculated $\mathrm{F}$ statistics and the error-correction term, which are found to be statistically significant in both $\mathrm{CO}_{2}$ and $\mathrm{y} / \mathrm{N}$ equations, but not in the ENC equation.

\section{Analysis Of Causality Test Based On Error-Correction Model}

Having found that there is a long-run relationship between $\mathrm{CO}_{2}, \mathrm{ENC}$ and $\mathrm{y} / \mathrm{N}$, the next step is to test for the causality between the variables used by incorporating the lagged error-correction term into equations (4), (5) and (6), respectively. The causality, in this case is, examined through the significance of the coefficient of the lagged error-correction term and joint significance of the lagged differences of the explanatory variables using the Wald test. The results of these causality tests are reported in Table 4. 
Table 4: Granger Non-Causality Test

\begin{tabular}{|c|c|c|c|c|}
\hline \multicolumn{4}{|c|}{ F-statistics [P-value] } & \multirow{2}{*}{$\begin{array}{l}\text { t - statistics } \\
\text { ECM }_{\text {t-1 }}\end{array}$} \\
\hline Dependent Variable & $\Delta \mathrm{InCO}_{2 \mathrm{t}}$ & $\Delta$ InENC $_{t}$ & $\Delta \mathbf{I n y} / \mathbf{N}_{\mathrm{t}}$ & \\
\hline$\Delta \operatorname{InCO}_{2 t}$ & - & $4.5558[0.0092]^{* * *}$ & $4.3825[0.0054] * * *$ & $\begin{array}{l}-0.8802 * * * \\
{[-4.736]}\end{array}$ \\
\hline$\Delta \mathrm{InENC}_{\mathrm{t}}$ & $0.46535[0.8732]$ & - & $0.80998[0.6163]$ & - \\
\hline$\Delta \operatorname{Iny} / \mathrm{N}_{\mathrm{t}}$ & $0.64094[0.7474]$ & $3.6248[0.0246]^{* *}$ & - & $\begin{array}{l}-4.212 * * * \\
{[-0.4979]}\end{array}$ \\
\hline
\end{tabular}

The empirical results reported in Table 4 show that there is both a short-run and a long-run unidirectional causal flow from economic growth to $\mathrm{CO}_{2}$ emissions in South Africa. The short-run causality is supported by the corresponding F-statistic in the $\mathrm{CO}_{2}$ emissions equation, which is statistically significant, while the long-run causality is supported by the lagged error-correction term, which is found to be negative and statistically significant. The results also show that energy consumption Granger-causes $\mathrm{CO}_{2}$ emissions without a feedback. This finding is supported by the corresponding F-statistic and the lagged error-correction term, which are statistically significant in the $\mathrm{CO}_{2}$ equation. Other results show that energy consumption Granger-causes economic growth both in the short run and in the long run. This is supported by the F-statistic and the coefficient of the lagged error-correction term, which are statistically significant in the economic growth equation, but insignificant in the energy consumption equation.

\section{CONCLUSION}

In this paper, we examine the causal relationship between $\mathrm{CO}_{2}$ emissions and economic growth in South Africa using the newly introduced ARDL-Bounds test. Specifically, we incorporate energy consumption in a bivariate setting between $\mathrm{CO}_{2}$ emissions and economic growth, thereby creating a simple trivariate model. Our empirical results show that there is a distinct unidirectional causal flow from economic growth to $\mathrm{CO}_{2}$ emissions in South Africa without a feedback. The results also show that energy consumption Granger-causes $\mathrm{CO}_{2}$ emissions and economic growth in South Africa. The results, however, failed to find any causal flow from $\mathrm{CO}_{2}$ emissions to either economic growth or energy consumption. The results apply irrespective of whether the causality is estimated in the short run or in the long run. The study, therefore, recommends that energy conservation policies, as well as appropriate forms of renewable energy, should be explored in South Africa in order to enable the country to reduce its carbon emission footprint without necessarily sacrificing its output growth.

\section{ABOUT THE AUTHOR}

Professor Nicholas M Odhiambo holds a PhD (Economics) degree from Stellenbosch University (South Africa) and a Masters degree in Economics from the University of Dar-es-salaam (Tanzania). Prof Odhiambo's research profile is broad, rich and multifaceted. During the past ten years, he has published more than 50 articles in 25 recognised journals. Prof Odhiambo is an NRF-rated researcher, and is listed in a number of international bibliographies and databases. Prof Odhiambo is currently working as Professor of Economics and Chair of Growth, Poverty and Policy Modelling Research (GPPMR) flagship at the University of South Africa (UNISA).

\section{REFERENCES}

1. Agras, J., Chapman, D., 1999. A dynamic approach to the environmental Kuznets curvehypothesis. Ecological Economics 28, 267-277.

2. Ang, J., 2007. $\mathrm{CO}_{2}$ emissions, energy consumption and output in France. Energy Policy 35, 4772-4778.

3. Apergis, N., Payne, J.E., 2009. $\mathrm{CO}_{2}$ emissions, energy use, and output in Central America. Energy Policy 37, 3282-3286.

4. Bhattacharyya, R., Ghoshal, T., 2009. Economic growth and $\mathrm{CO}_{2}$ emissions. Environmental Development and Sustainability (Online version - DOI 10.1007/s10668-009-9187-2).

5. Cropper, M., Griffiths, C., 1994. The interaction of population growth and environmental quality. American Economic Review 84, 250-254. 
6. Elliot, G., Rothenberg, T., Stock J., 1996. Efficient tests for an autoregressive unit root. Econometrica 64, 813-36.

7. Engle, R.F., Granger, C.J., 1987. Cointegration and error-correction - representation, estimation and testing. Econometrica 55, 251-78.

8. Ferda, H., 2008. An Econometric study of $\mathrm{CO}_{2}$ emissions, energy consumption, income and foreign trade in Turkey. A paper presented at the $31^{\text {st }}$ IAEE Annual International Conference, Instanbul - Turkey (June).

9. Grossman, G., Krueger, A., 1995. Economic environment and the economic growth. Quarterly Journal of Economics 110(2), 353-377.

10. Halicioglu, F., 2009. An econometric study of $\mathrm{CO}_{2}$ emissions, energy consumption, income and foreign trade in Turkey. Energy Policy 37, 1156-1164.

11. Hettige, H., Lucas, R.E.B., Wheeler, D., 1992. The toxic intensity of industrial production: global patterns, trends, and trade policy. American Economic Review 82, 478-481

12. Holtz-Eakin, D., Selden, T.M., 1995. Stocking the fires? $\mathrm{CO}_{2}$ emissions and economic growth. Journal of Public Economics 57, 85-101.

13. Jinke, L., Hualing, S., and Dianming, G., 2007. Causality relationship between coal consumption and GDP: Difference of major OECD and non-OECD countries. Applied Energy 85(6), 421-429.

14. Johansen, S., 1988. Statistical analysis of cointegration vectors. Journal of Economic Dynamics and Control 12, 231-54.

15. Johansen, S., Juselius, K., 1990. Maximum likelihood estimation and inference on cointegration with applications to the demand for money. Oxford Bulletin of Economics and Statistics 52, 169-210.

16. Lise, W., 2006. Decomposition of $\mathrm{CO}_{2}$ emissions over 1980-2003. Energy Policy 34, 1841-1852.

17. Martinez-Zarzoso, I., Bengochea-Morancho, A., 2004. Pooled mean group estimation of an environmental Kuznets curve for $\mathrm{CO}_{2}$. Economics Letters 82, 121-126.

18. Morley, B., 2006. Causality between economic growth and migration: an ARDL bounds testing approach. Economics Letters 90, 72-76.

19. Narayan, P.K., Smyth, R., 2006. Higher education, real income and real investment in China: evidence from Granger causality tests. Education Economics 14, 107-125.

20. Narayan, P.K., Prasad, A., 2008. Electricity consumption - real GDP causality nexus: Evidence from a bootstrapped causality test for 30 OECD countries. Energy Policy 36, 910-918.

21. Narayan, P.K., Smyth, R., 2008. Energy consumption and real GDP in G7 countries: New evidence from panel cointegration with structural breaks. Energy Economics 30, 2331-2341.

22. Newey, W.K., West, K.D., 1987. A simple, positive semi-definite, heteroskedasticity and autocorrelation consistent covariance matrix. Econometrica 55, 703-8.

23. Odhiambo, N.M., 2008. Financial depth, savings and economic growth in Kenya: a dynamic casual relationship. Economic Modelling 25 (4), 704-713.

24. Odhiambo, N.M., 2009a. Energy consumption and economic growth nexus in Tanzania: an ARDL bounds testing approach. Energy Policy 37(2), 617-622.

25. Odhiambo, N.M., 2009b. Electricity consumption and economic growth in South Africa: A trivariate causality test. Energy Economics 31(5).

26. Pesaran, M., Pesaran, B., 1997. Working with microfit 4.0: interactive economic analysis. Oxford University Press, Oxford.

27. Pesaran, M., Shin, Y., 1999. An autoregressive distributed lag modeling approach to cointegration analysis in S. Strom, (ed) Econometrics and Economic Theory in the $20^{\text {th }}$ Century: The Ragnar Frisch centennial Symposium, Cambidge University Press, Cambridge.

28. Pesaran, M., Shin, Y., Smith, R., 2001. Bounds testing approaches to the analysis of level relationships. Journal of Applied Econometrics 16, 289-326.

29. Sadorsky, P., 2009. Renewable energy consumption, $\mathrm{CO}_{2}$ emissions and oil prices in $\mathrm{G} 7$ countries. Energy Economics 31, 456-462.

30. Sari, R., Soytas, U., 2009. Are global warming and economic growth compatible? Evidence from five OPEC countries. Applied Energy 86, 1887-1893.

31. Selden, T.M., Song, D., 1994. Environmental quality and development: is there a Kuznets curve for air pollution emissions? Journal of Environmental Economics and Management 27, 147-162.

32. Shiafik, N., 1994. Economic development and environmental quality: an economicnanalysis. Oxford Economic Papers 46, 757-773. 
33. Soytas, U., Sari, R., Ewing, T., 2007. Energy consumption, income and carbon emissions in the United States. Ecological Economics 62, 482-489.

34. Soytas, U., Sari, R., 2009. Energy consumption, economic growth and carbon emissions: Challenges faced by an EU candidate member. Ecological Economics 68, 1667-1675.

35. Sun, J.W., 1999. The nature of $\mathrm{CO}_{2}$ emission Kuznets curve. Energy Policy 27 (12), 691-694.

36. World Bank, 2007. Growth and $\mathrm{CO}_{2}$ emissions: How do different countries fare? Environment Department (October). 
NOTES 